\title{
THE INFLUENCE OF WATER HARDNESS AND DIETARY CALCIUM ON GROWTH AND SURVIVAL OF POSTLARVAL PRAWN, Macrobrachium rosenbergii
}

\author{
M. Fatuchri Sukadi*)
}

\begin{abstract}
The influence of water hardness on survival of freshwater prawn, Macrobrachium rosenbergii was investigated in indoor tanks during a 132-day study. An evaluation was also carried out to determine the influence of water hardness and dietary calcium on growth and survival of postlarval prawn in an 18-week study. Water hardness levels of 18, 35, 150, and $300 \mathrm{mg} / \mathrm{L}$ as $\mathrm{CaCo}_{3}$ and dietary calcium levels of $0.25,2.00$ and $4.00 \%$ were used as treatment levels. There was no evidence that the final weight of postlarvae prawn was influenced by water hardness $(P>0.05)$. However, there was an effect of water hardness on survival of postlarval prawns $(\mathrm{P}<0.05)$. Survival of postlarvae decreased linearly from 51.4 to $26.0 \%$ as water hardness increased from 18 to $300 \mathrm{mg} / \mathrm{L}$. Total body calcium and ash were not influenced by water hardness $(\mathrm{P}>0.05)$.
\end{abstract}

KEYWORDS: water hardness, giant freshwater prawn, dietary calcium, growth and survival, Macrobrachium rosenbergii.

\section{INTRODUCTION}

Prawns require minerals, especially calcium and magnesium, for new exoskeleton formation as well as other biological processes. References to dietary mineral requirements of prawns are scarce, although most workers have used mineral supplements in prepared diets (New, 1976).

Study involving calcium in aquatic systems is complicated because of the presence of available calcium in the water (Robinson et al., 1984). Calcium, from which most skeletal salts which strengthen the exoskeleton are made, is the most important mineral source for a successful molt in prawns (Fieber \& Lutz, 1982). Molting is a critical event in the life cycle of crustaceans (Feiber \& Lutz, 1982); therefore, a successful molt is necessary for growth and survival of the prawn.

Calcium is required in rather high levels by animals as compared to other mineral elements (Robinson et $a l$., 1987). In fish, calcium is required for the formation of skeletal tissue, blood clotting, muscle functions, proper nerve impulse transmissions, osmoregulation, and serves as cofactor during various enzymatic processes (NRC, 1983). Not only that crustacea have all of these same calcium requirements but also have the additional requirement for calcification of new shells after molting through the crustacean life cycle (Fieber \& Lutz, 1982).
For marine shrimp, Penaeus japonicus, Deshimaru \& Yone (1978) found that a supplement of $2 \%$ calcium to the diet did not improve growth. Marine shrimp were found to absorb more calcium from seawater if there was a lack of calcium in the diet (Deshimaru et al., 1978). In a study with $P$. californiensis, Huner \& Colvin (1977) showed a decline in growth performance with dietary calcium at $3 \%$, but a consistently good growth with dietary calcium beween $2.06 \%-2.42 \%$. All diets contained $1 \%$ phosphorus. Growth was inhibited and pigmentation decreased in P. japonicus when the calciumphosphorus ratio increased to $2: 1$ (New, 1976).

Calcium levels in freshwater are usually much lower than those in seawater. Robertson (1941) mentioned that calcium levels in most freshwater rivers and streams ranged between $1.120 \mathrm{mg} / \mathrm{L}$ and in seawater was usually about $400 \mathrm{mg} / \mathrm{L}$. Freshwater prawns would appear to have similar calcium requirements for molting and other metabolic functions as marine shrimp. While water hardness (up to $300 \mathrm{mg} / \mathrm{L}$ as $\mathrm{CaCo}_{3}$ ) was found not to affect the spawning and egg production of giant freshwater prawn, $M$. rosenbergii (Sukadi, 1995), the question arises then, as to the influences which dietary calcium have on prawn growth and survival at various levels of water hardness.

This study was conducted to investigate the influence of total water hardness and dietary

\footnotetext{
*) Researcher of the Central Research Institute for Fisheries, Jakarta
} 
calcium on growth and survival of postlarval prawns, $M$. rosenbergii.

\section{MATERIALS AND METHODS}

\section{Postlarval Prawns}

Prawn postlarvae ( $M$. rosenbergii) were grown in hapas for 18 weeks in fiberglass tanks. Three levels of water hardness with three replicates each were randomly assigned among nine $1.4 \mathrm{~m}^{3}$ tanks.

The three levels of water hardness were: 18 $\mathrm{mg} / \mathrm{L}\left(7.4 \mathrm{mg} / \mathrm{L} \mathrm{Ca}^{++}\right), 150 \mathrm{mg} / \mathrm{L}\left(56.1 \mathrm{mg} / \mathrm{L} \mathrm{Ca}^{++}\right)$ and $300 \mathrm{mg} / \mathrm{L}\left(109.9 \mathrm{mg} / \mathrm{L} \mathrm{Ca}{ }^{++}\right)$. The different levels of water hardness were prepared by adding agricultural gypsum, $\mathrm{CaSO}_{4} \cdot 2 \mathrm{H}_{2} \mathrm{O}$, to well water with a hardness of $18 \mathrm{mg} / \mathrm{L}$. No gypsum was needed for the low hardness level. Each tank was equipped with a gravel biofilter and two air lift pumps for filtration and aeration. Three hapas were suspended in each tank (Figure 1). Hapas were made from a single piece of fiberglass window screen ( 7 meshes/cm) as described by Tave $\&$ Tave (1984). Each hapa was approximately 65 $\mathrm{cm}$ long, $50 \mathrm{~cm}$ wide and $25 \mathrm{~cm}$ deep.

Three diets were prepared, each with a different level of calcium (Table 1). The protein content of the diets was $37 \%$. The diets with calcium levels of $0.26,2.12$ and $3.98 \%$ were each randomly assigned to one of three hapas placed in each tank. The treatment combinations using three levels of water hardness and three levels of dietary calcium gave a split-plot design, where tanks were considered as whole-plots and hapas as sub-plots.

The tanks were partially covered by black plastic sheets to prevent prawns from jumping out of the hapas and to reduce algal growth during the studies. The $\mathrm{pH}$, water hardness, nitrite, and ammonia were monitored every two weeks with a Hach Kit model FF-1A. Tanks were siphoned weekly and make-up water was added as needed. The $\mathrm{pH}$ ranged from 6.5-7.0 throughout the

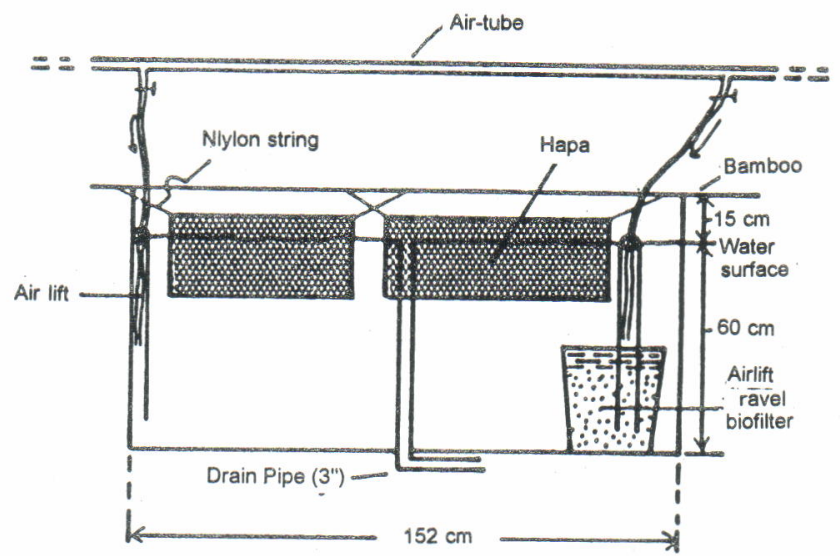

(A)

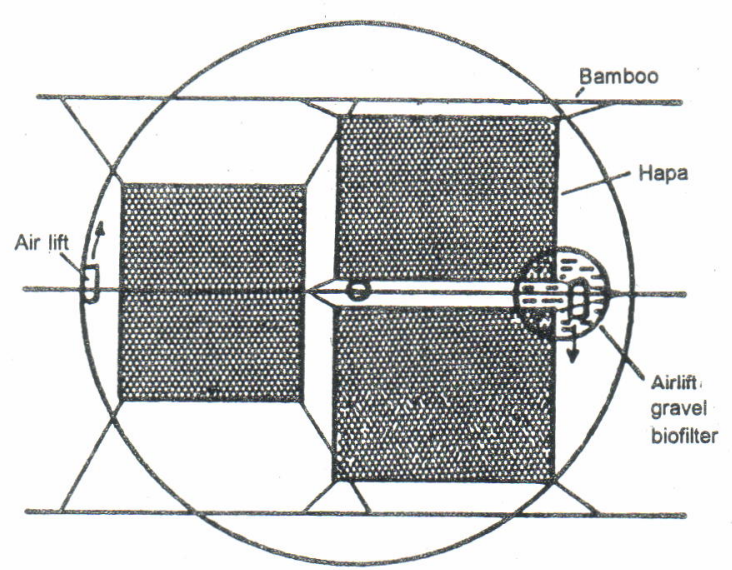

(B)

Figure 1. Hapas and nursery tank for rearing postlarval prawns.

(A) side view, (B) top view. 
Table 1. Composition of postlarval prawns diet.

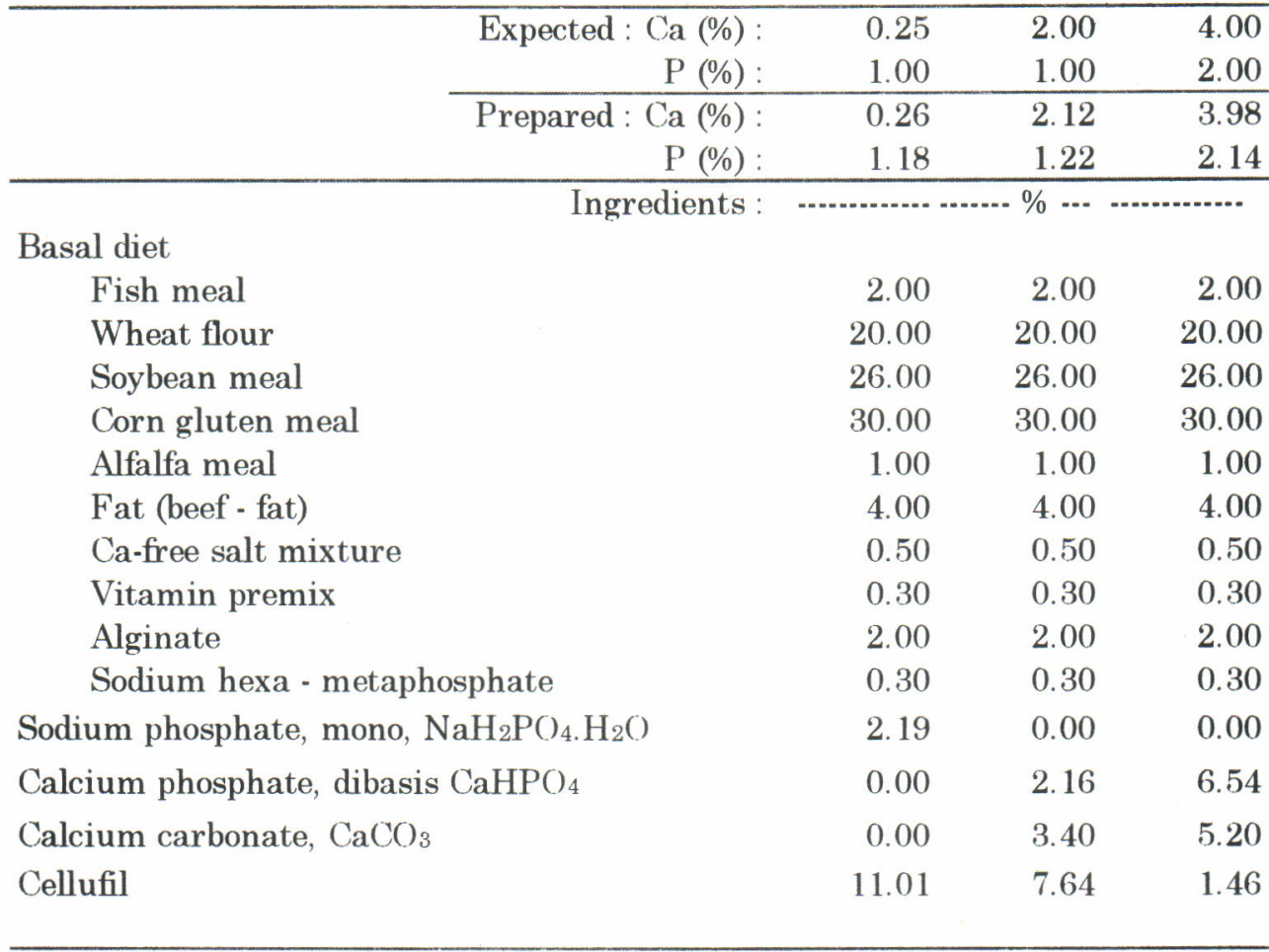

1 Donated by Jazz Feed, Cosby-Hodges Co. Birmingham, Alabama

2 Dipotassium phophate $52.873 \%$, monosodium phosphate $10.313 \%$, magnesium phosphate $8.188 \%$, sodium chloride $23.125 \%$, ferric citrate $4.500 \%$, potassium iodide $0.130 \%$, manganese sulfate $0.741 \%$, zincchloride $0.080 \%$, copper sulfate $0.050 \%$ (Biochemical, 1984).

3 Amount (g) for $2 \mathrm{~kg}$ diet: Vit. A acetate (20,000 USP/g) 1.64, Chole-calciferol (1,000,000 USP/g) 0.0082 , ribo-flavin 0.1916 , pantothenic acid 0.0546 , niacin 0.1916 , menadione sodium bisulfite 0.1066 , folacin 0.0036 , pyridoxine hydro-chloride 0.0372 , thiamine mononitrite 0.0372 , biotin 0.0012 , ascorbic acid 0.0496 , ethoxyquin 0.5210 , choline chloride 1.2400 , oxytetracycline 0.0400 , methionine hydroxy analogue 2.4816 (Andrews et al ., 1973).

experiment. Biofilters, siphoning and water exchange were made sufficient to keep nitrite and ammonia levels below $0.3 \mathrm{mg} / \mathrm{L}$ throughout the experiment. Water temperatures were monitored daily and maintained within the range of $26^{\circ}-30^{\circ} \mathrm{C}$ with heaters. Dissolved oxygen measured with an YSI Model 57 oxygen meter remained about $5 \mathrm{mg} /$ $\mathrm{L}$ in all tanks throughout the experiment. Additional strips of substratum made from fiberglass window screen were set vertically in each hapa to give a total surface area of $1.15 \mathrm{~m}^{2}$, including the inside surfaces.

Each hapa received 50 postlarvae (PL) obtained from a commercial prawn hatchery. This stocking rate resulted in a density of $0.8 \mathrm{PL} / \mathrm{L}$ of hapa volume or $43 \mathrm{PL} / \mathrm{m}^{2}$ of total hapa area. The initial weight of the PL averaged $0.014 \mathrm{~g}$. Initial total body ash was $15.51 \%$ on a dry matter basis. Diets were fed to the PL daily between 4:00-5:00 pm. Alginate and sodium hexa-metaphosphate were added to the diets while pelleting to obtain a water stability of 24 hours was as described by Heinen (1981). Dietary calcium was determined by the method described by Hue \& Evans (1986).

Prawn weights were measured every three weeks beginning from week six of the experiment. For the last sampling, all prawns were harvested, counted, weighed and frozen for analysis. Total body ash was analyzed by the method described by Lovell (1981), and total body calcium was determined with an Inductively Coupled Argon Plasma Spectrometer, ICAP (Hue \& Evans, 1986). 
Analysis of variance was applied to observations for final weight, survival rate, total body calcium, and ash. Differences among treatment means were examined by selected contrasts (Steel \& Torrie, 1980).

\section{RESULTS AND DISCUSSION}

\section{Growth of Postlarval Prawns}

Average final weights of postlarvae, after 18 weeks of culture in hapas, ranged from $1.32 \mathrm{~g}$ in water of $300 \mathrm{mg} / \mathrm{L}$ to $1.40 \mathrm{~g}$ in water of $18 \mathrm{mg} / \mathrm{L}$ hardness. Average final weights of postlarvae on different diets ranged from $1.26 \mathrm{~g}$ with the low calcium diet to $1.45 \mathrm{~g}$ with the high calcium diet (Table 2). There was no evidence that the final weights of postlarval prawns were different $(\mathrm{P}>0.05)$. Growth rates obtained in this study were similar to those obtained in other tank studies (Figure 2). Sandifer \& Smith (1985) studied postlarval growth in indoor systems and reported that postlarval prawns generally gained weights of $0.5 \cdot 1.0^{+} \mathrm{g}$ after 8 to 12 weeks of rearing when starting with PL densities of 750-3,000 $\mathrm{PL} / \mathrm{m}^{2}$.

The 1.3-1.4 final weights obtained in this study after 18 weeks with a density of $153 \mathrm{PL} / \mathrm{m}^{2}$ were comparable with the results reported by Sandifer and Smith (1985). Heinen (1977) found that there were no significant differences among final weights of postlarvae reared in water hardnesses from 10$310 \mathrm{mg} / \mathrm{L}$ after 28 days rearing. However, Vasquez (1984) found that a water hardness of 225 and 450 $\mathrm{mg} / \mathrm{L}$ had a detrimental effect on the growth of prawn.

Aquacop et al. (1989) reported that the final weights of juvenile prawns reared in water hardness levels of 25 and $125 \mathrm{mg} / \mathrm{L}$ were not significantly different. Observed mean weights for post- larval prawns in the study decreased as water hardness increased; however, differences were not significant $(P>0.05)$.

From these data, it appears that a dietary level of calcium around $0.25 \%$ provides enough calcium for postlarval prawn, even in waters with a hardness of $18 \mathrm{mg} / \mathrm{L}$. In channel catfish, dietary levels of calcium above $0.05 \%$ had no significant effect on growth in water of $14 \mathrm{mg} / \mathrm{L}$ hardness (Lovell $\& \mathrm{Li}, 1978$ ). Japanese eels required approximately $0.27 \%$ dietary calcium when reared in water containing $19 \mathrm{mg} / \mathrm{L}$ calcium (NRC, 1983).

\section{Survival of Postlarval Prawns}

Mean survival of postlarvae by water hardness treatments ranged from $51.4 \%$ at a hardness of $18 \mathrm{mg} / \mathrm{L}$ to $26.0 \%$ at a hardness of $300 \mathrm{mg} / \mathrm{L}$ (Table 3). Mean survival decreased from 40.9 to $33.3 \%$ as dietary calcium increased from 0.26 to $3.98 \%$. Survival rates were significantly different for postlarvae in waters of different hardnesses $(\mathrm{P}<0.05)$. However, differences in prawn survival were not significant with the different diets and there was no interaction effect between water hardness and $\operatorname{diet}(\mathrm{P}>0.05)$.

Heinen (1977) reported no significant effect of water hardness of $10-310 \mathrm{mg} / \mathrm{L}$ as $\mathrm{CaCO}_{3}$ on survival after four weeks of culture. The longer culture period (18 weeks) in this study is thought to be the reason for the greater differences in survival obtained.

Differences in survival among treatments did not begin to show up until after week nine. There was no clear reason for the changes in survival occurring from the ninth week to the end of the study. Growth of postlarvae was consistent throughout the experiment. No major changes in

Table 2. Average final weight $(\mathrm{g})$ of postlarval prawns, after 18 weeks of culture in waters of different hardness and receiving diets with different levels of calcium. All values are the mean of three replicates.

\begin{tabular}{|c|c|c|c|c|c|}
\hline \multirow{2}{*}{ Diet } & \multirow{2}{*}{$\begin{array}{c}\text { Dietary } \\
\text { calcium } \\
(\%)\end{array}$} & \multicolumn{3}{|c|}{$\begin{array}{l}\text { Water hardness } \\
\left(\mathrm{mg} / \mathrm{L} \text { as } \mathrm{CaCO}_{3}\right)\end{array}$} & \multirow{2}{*}{$\begin{array}{c}\text { Means } \\
(\mathrm{S} . \mathrm{E} .=0.10)\end{array}$} \\
\hline & & 18 & 150 & 300 & \\
\hline 1 & 0.26 & 1.25 & 1.20 & 1.33 & 1.26 \\
\hline 2 & 2.12 & 1.48 & 1.39 & 1.32 & 1.40 \\
\hline 3 & 3.98 & 1.47 & 1.56 & 1.31 & 1.45 \\
\hline \multicolumn{2}{|c|}{$\begin{array}{l}\text { Means: } \\
(\text { S.E. }=0.10)\end{array}$} & 1.40 & 1.38 & 1.32 & \\
\hline
\end{tabular}



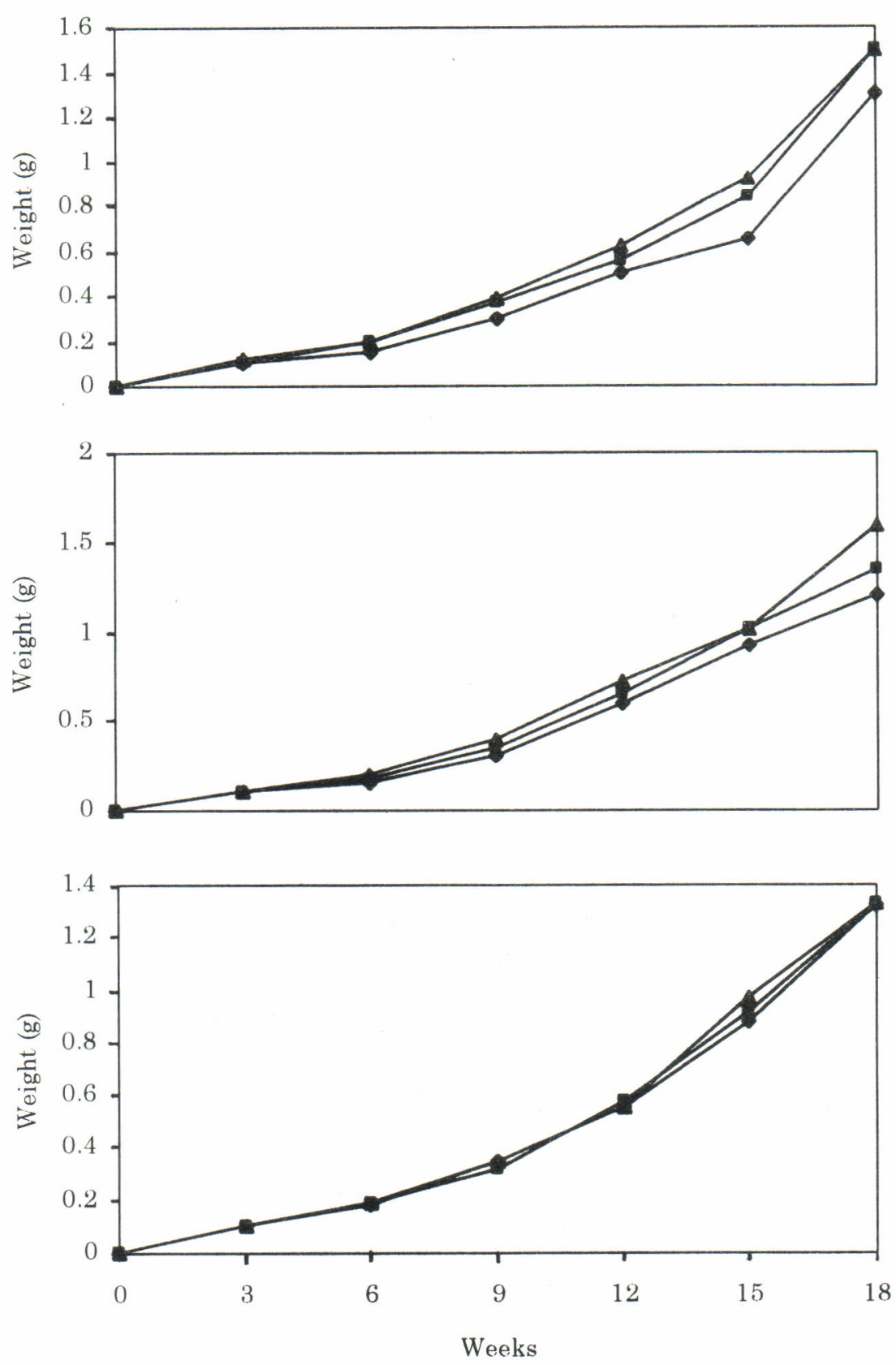

$\multimap \mathrm{Ca}: 2.12 \% \rightarrow \mathrm{Ca}: 3.98 \% \multimap \mathrm{Ca}: 0.26 \%$

Figure 2. Growth of postlarval prawns in nursery tanks during 18 weeks of culture in water of $18,150,300 \mathrm{mg} / \mathrm{L}$ hardness and receiving dietary calcium levels of $0.26 \%, 2.12 \%$, and 3.98\%. Top Graph: Growth in $18 \mathrm{mg} / \mathrm{L}$, Middle: $150 \mathrm{mg} / \mathrm{L}$, and Bottom: $300 \mathrm{mg} / \mathrm{L}$.

growth were evident during the sampling periods between week-9 and week-18. It is possible that physiological changes in the prawns occurred during this time causing lower survivals at the higher hardness levels, or that internal calcium reserves in postlarvae had not accumulated to a harmful level until after nine weeks. Additional studies are needed to understand the reasons for lower survival at high hardness levels with postlarvae after 9-18 weeks.

The importance of dissolved calcium in water for prawns during molting has been shown by Passano (1960), Fieber \& Lutz (1982). Cripps \& Nakamura (1979) reported slower growth and long molt cycles in prawns in harder waters. In this study, observed mean levels of total body 


\section{M.F. Sukadi}

Table 3. Average survival (\%) of postlarval prawns after 18 weeks of culture in water of different hardnesses and fed diets with different dietary calcium. All values are the mean of three replicates.

\begin{tabular}{cccccc}
\hline Diet & $\begin{array}{c}\text { Dietary } \\
\text { calcium } \\
(\mathbf{\%})\end{array}$ & \multicolumn{3}{c}{$\begin{array}{c}\text { Water hardness } \\
\left(\mathbf{m g} / \mathrm{L} \text { as } \mathbf{C a C O}_{3}\right)\end{array}$} & $\begin{array}{c}\text { Means } \\
\text { (S.E.=2.8) }\end{array}$ \\
\cline { 3 - 5 } & & $\mathbf{1 8}$ & $\mathbf{1 5 0}$ & $\mathbf{3 0 0}$ & \\
\hline 1 & 0.26 & 64.7 & 35.3 & 22.7 & 40.9 \\
2 & 2.12 & 44.7 & 34.7 & 29.3 & 36.2 \\
3 & 3.98 & 44.7 & 29.3 & 26.0 & 33.3 \\
\hline & Means & 51.4 & 33.1 & 26.0 & \\
\hline
\end{tabular}

calcium increased as water hardness increased (Table 4). It is not clear if these relatively slight increases in total body calcium represented accumulated levels critical to survival or if other factors occurred. Anions such as $\mathrm{SO}_{4}$ and $\mathrm{Cl}$ were found to decrease the rate of calcium uptake following molting in studies with the freshwater crayfish, Autopotamobius pallipes (Greenaway, 1974).

If increased levels of $\mathrm{SO}_{4}$ had been a factor influencing survival in this study, the effects should had been evident from the beginning. In this study survivals were similar in all treatments for the first nine weeks. The data from this study support the earlier hypothesis, that physiological changes in prawns occur after about nine weeks or that accumulations of calcium occur slowly and do not reach critical levels until about nine weeks.

The survival rates of postlarvae over time during this experiment are shown in Figures 3. The survival rate of postlarvae remained over $80 \%$ during the first six weeks at all levels of water hardness and then dropped to the final levels of about 45,33 and $26 \%$ at water hardness levels of 18,150 and $300 \mathrm{mg} / \mathrm{L}$, respectively.

\section{Total Body Calcium}

Average total body calcium of prawns after 18 weeks of culture in hapas ranged from $3.65 \%$ for PL in $18 \mathrm{mg} / \mathrm{L}$ hardness to 3.89 and $3.90 \%$ for $\mathrm{PL}$ in 300 and $150 \mathrm{mg} / \mathrm{L}$ hardnesses, respectively. Total body calcium for PL receiving different dietary calcium levels ranged from $3.36 \%$ for $\mathrm{PL}$ receiving the low calcium diet to $4.38 \%$ for $\mathrm{PL}$ receiving the high calcium diet (Table 4). There were no significant differences among means for the different treatments. However, total body calcium increased linearly as calcium in the diet increased $(\mathrm{P}<0.05)$

In fingerling Tilapia aurea reared in calcium. free water and fed dietary phosphorus $0.05 \%$ diet, levels of dietary calcium exceeding $0.65 \%$ generally did not improve bone mineralization (Robinson et al., 1984). Vertebral bone calcium of channel catfish, reared in calcium-free water re-

Table 4. Average total body calcium (\%) of prawns after 18 weeks of culture in water of different hardnesses and receiving feeds of different dietary calcium. All treatments had three replications.

\begin{tabular}{lcccc}
\hline \multicolumn{1}{c}{$\begin{array}{c}\text { Dietary } \\
\text { calcium } \\
(\%)\end{array}$} & \multicolumn{3}{c}{$\begin{array}{c}\text { Water hardness } \\
\left(\mathbf{m g} / \mathrm{L} \text { as } \mathrm{CaCO}_{3}\right)\end{array}$} & $\begin{array}{c}\text { Means } \\
\text { (S.E. }=\mathbf{2 . 8})\end{array}$ \\
\cline { 2 - 5 } & $\mathbf{1 8}$ & $\mathbf{1 5 0}$ & $\mathbf{3 0 0}$ & \\
\hline 0.26 & 3.80 & 2.91 & 3.38 & 3.36 \\
2.12 & 2.61 & 4.33 & 4.18 & 3.71 \\
3.98 & 4.45 & 4.48 & 4.11 & 4.38 \\
\hline $\begin{array}{l}\text { Means: } \\
\text { (S.E.=2.8) }\end{array}$ & 3.65 & 3.90 & 3.89 & \\
\hline
\end{tabular}



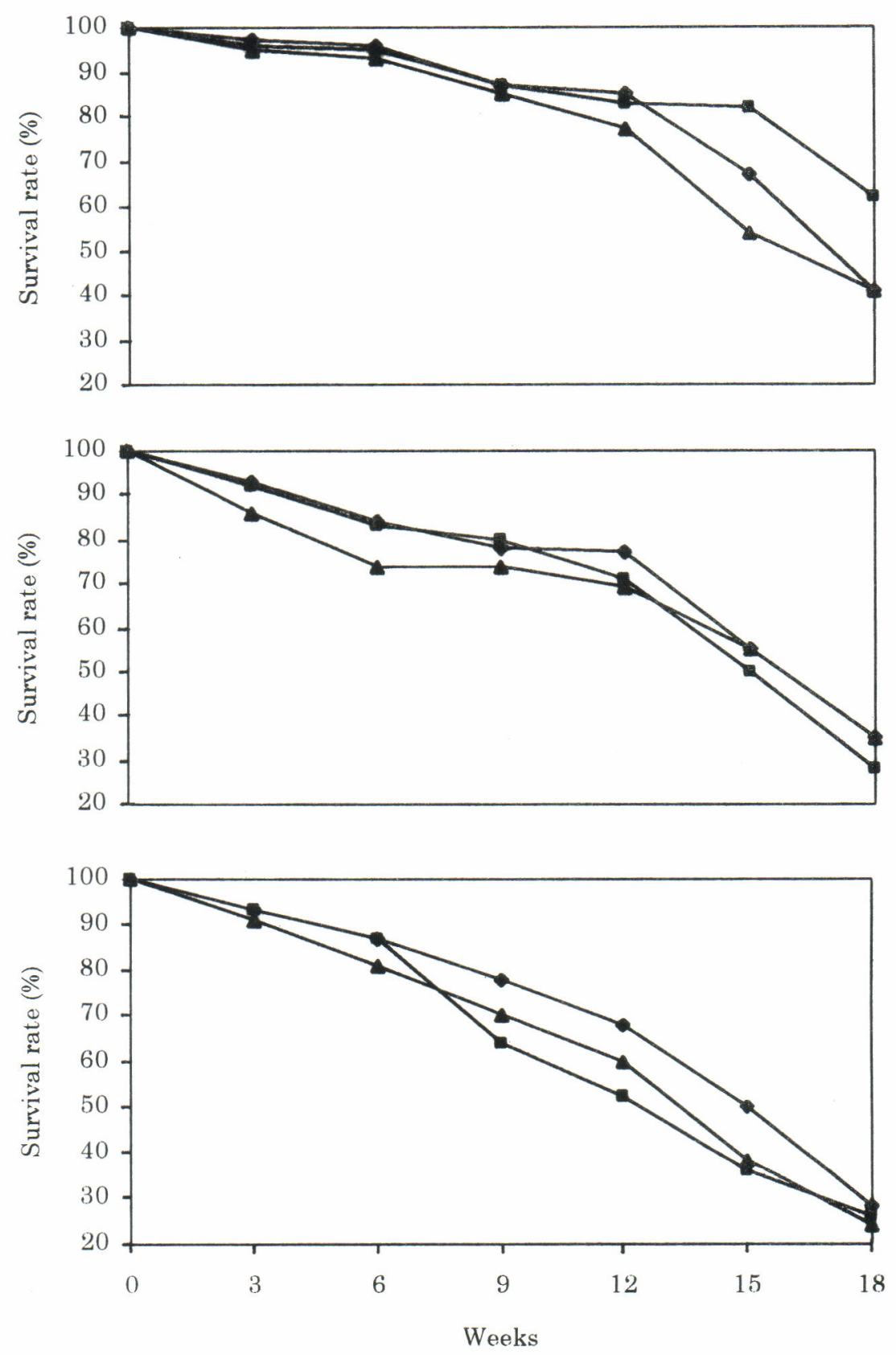

$\multimap \mathrm{Ca}: 2.12 \% \rightarrow \mathrm{Ca}: 3.98 \% \multimap \mathrm{Ca} 0.26 \%$

Figure 3. Survival rates of postlarval prawns in nursery tanks during 18 weeks of culture in waters with different hardnesses and receiving feeds of different dietary calcium. Top graph: $18 \mathrm{mg} / \mathrm{L}$ water hardness, Middle: $150 \mathrm{mg} / \mathrm{L}$, and Bottom: $300 \mathrm{mg} / \mathrm{L}$.

mained relatively constant also at dietary calcium ranged from $0.17 \%$ to $0.85 \%$ with dietary phosphorus $0.50 \%$ (Robinson et al., 1986).

Observed mean weights with different diets increased as dietary calcium increased (Table 2). Total body calcium also increased as dietary calcium increased.

\section{Total Body Ash}

There were no significant differences between means for total body ash for treatments of water hardness or diet. Means of total body ash in dry weight bases ranged from 17.39 to $18.78 \%$ by water hardness treatments and from 17.92 to $18.14 \%$ inversely by diet (Table 5 ). 


\section{M.F. Sukadi}

Table 5. Average total body ash (\% dry weight) of prawns after 18 weeks of culture in water of different hardnesses and receiving feeds of different levels of dietary calcium. All treatments had three replicates.

\begin{tabular}{ccccc}
\hline \multirow{2}{*}{$\begin{array}{c}\text { Dietary } \\
\text { calcium } \\
\text { (\%) }\end{array}$} & \multicolumn{3}{c}{$\begin{array}{c}\text { Water hardness } \\
\left.\text { (mg/L as } \mathrm{CaCO}_{3}\right)\end{array}$} & $\begin{array}{c}\text { Means } \\
\text { (S.E.=2.8) }\end{array}$ \\
\cline { 2 - 5 } & $\mathbf{1 8}$ & $\mathbf{1 5 0}$ & $\mathbf{3 0 0}$ & \\
\hline 0.26 & 16.75 & 18.66 & 18.59 & 18.00 \\
2.12 & 18.01 & 18.82 & 17.59 & 18.14 \\
3.98 & 17.41 & 17.58 & 18.78 & 17.92 \\
\hline $\begin{array}{l}\text { Means: } \\
\text { (S.E. =0.60) }\end{array}$ & 17.39 & 18.35 & 18.78 & \\
\hline
\end{tabular}

The means which ranged from 17.39 to $18.78 \%$ were within the range reported by Sze (1973) (15.9\%), and Iwai (1976) (21.3\%). Bone mineralization indicated by ash content was not improved by dietary calcium higher than $0.65 \%$ in Tilapia aurea (Robinson et al., 1986) and $0.17 \%$ in channel catfish (Robinson et al., 1986) when maintained in calcium-free water.

The results of this study indicate freshwater prawn may also be able to obtain sufficient calcium for shell formation and growth from surrounding water, even in minerally soft waters.

\section{CONCLUSION}

There were no significant differences in final weight of postlarvae prawn in the different treatments of water hardness or dietary calcium $(\mathrm{P}>0.05)$.

Survival of postlarval prawns was significantly affected by water hardness. Survival rates decreased in linear fashion $(\mathrm{P}<0.05)$ from 51.4 to $26.0 \%$ as water hardness increased from 18 to 300 $\mathrm{mg} / \mathrm{L}$. There were also no significant effects of dietary calcium on survival of prawn

There were no significant differences among means of total body calcium or total body ash of prawns for different treatments of water hardness or dietary calcium $(P>0.05)$. There was also no interaction effect between water hardness and diet on total body calcium and total body ash $(\mathrm{P}>0.05)$.

The results of this study suggest that even in minerally soft waters $\left(18 \mathrm{mg} / \mathrm{L}\right.$ as $\left.\mathrm{CaCO}_{3}\right)$, enough calcium is available for good growth and survival of prawns. At the highest hardness levels evaluated, $300 \mathrm{mg} / \mathrm{L}$ as $\mathrm{CaCO}_{3}$, growth rates were reduced and mortality rates increased. Prawns were able to obtain sufficient calcium from the water. Changing the levels of dietary calcium had no effect on growth and survival of prawns.

\section{ACKNOWLEDGEMENTS}

This research was conducted at the Fisheries Research Unit, Alabama Agricultural Experiment station and was part of dissertation (Sukadi, 1989) submitted by the author to Department of Fisher. ies and Allied Aquculture, Auburn University.

The author is grateful to Dr. D.B. Rouse, Dr. R.O. Smitherman, Dr. R.T. Lovell, Dept. of Fisheries and Allied Aquaculture; Dr. Ann H. Williams Dept. of Zoology and Wildlife Science, and Dr. John C. Williams, Research Data Analysis, Auburn University for their critical reviews of this manuscript and for their support for this study. Financial support for this study was from the Agency for Agricultural Research and Development (AARD), Republic of Indonesia.

\section{REFERENCES}

Andrews, J.W., Murai, T. and Campbell, C. 1973. Effects of dietary calcium and phosphorus on growth, food conversion, bone ash and hematocrit levels of catfish. J. Nutr. 103: 766-771.

Aquacop, E. Bedier and Deschamps, (x. 1989. Chronic effect of low calcium concentration and high $\mathrm{pH}$ on the growth and mortality of Macrobrachium rosenbergii (de Man). Aquaculture '89. WAS Meeting Abstracts. February 12-16. Los Angeles.

Biochemical. 1984. United States Biochemical Corporation. USB Cleveland Ohio.

Cripps M.C. and Nakamura, R.M. 1979. Inhibition of growth of Macrobrachiium rosenbergii by calcium carbonate water hardness. Proc. World Maricul. Soc. 10: 575-580. 
Deshimaru, O. and Yone, Y. 1978. Requirement of prawn for dietary minerals. Bull. Jap. Soc. Sci. Fish. 44(8): 907-910.

Deshimaru, O., Kuroki K., Sakamoto, and Yone, Y. 1978. Absorption of labelled calcium $-{ }^{45}$ Ca by prawn from sea water. Bull. Jap. Soc. Sci. Fish 44(9): 975 977.

Fieber, L. A. and P. L. Lutz. 1982. Calcium requirements for molting in Macrobrachium rosenbergii. J. World Maricult. Soc. 13: 21-27.

Greenaway, P. 1974. Calcium balance at the postmoult stage of the freshwater crayfish Austropotamobius pallipes (Lereboullet). J. Expt. Biol. 61:35-45.

Heinen, J. M. 1977. Influenced of Dissolved Calcium and Magnesium on Postlarval Growth of the Freshwater Shrimp Macrobrachium rosenbergii. M.S. Thesis. Florida Atlantic Univ.

Heinen, J.M. 1981. Evaluation of some binding agents for crustacean diets. Prog. Fish Cult. 43(3) : 142145.

Hue, N.V. and Evans, C.E. 1986. Procedures Used for Soil and Plant Analysis by the Auburn University Soil Testing Laboratory. Dept. of Agronomy and Soils. Dept. Series No. 106. Auburn University, Al.

Huner, J.V. and Colvin, L.B. 1977. A short term study on the effects of diets with varied calcium: phosphorus ratios on the growth of juvenile shrimp, Penaeus californiensis (Penaeidae: Crustacea). Proc. World Maricult. Soc. 8: 775-778.

Iwai, T. 1976. Energy Transformation and Nutrient Assimilation by the Freshwater Prawn, Macrobrachium rosenbergii under Controlled Laboratory Conditions. M.S. Thesis. Univ. of Hawaii, Honolulu.

Lovell, R.T. 1981. Laboratory Manual for Fish Feed Analysis and Fish Nutrition Studies. Int'l Center Aquacul. Auburn Univ.

Lovell, R.T. and Li, Y.P. 1978. Essentiality of vitamin $\mathrm{D}$ in diets of channel catfish (Ictalurus punctatus). Trans. Am. Fish. Soc. 107: 809-811.

New, M.B. 1976. A review of dietary studies with shrimp and prawns. Aquaculture 9: 101-144.

NRC. 1983. Nutrient Requirement of Warmwater Fishes and Shellfishes. Nat. Acad. Press. Washington D.C.
Passano, L.M. 1960. Molting and its control. In: Waterman., T.H. (Ed.). The Physiology of Crustacea. Vol. I. Metabolism and Growth. Academic Press. New York. p. 473-536.

Robertson, J.D. 1941. The function and metabolism of calcium in the invertebrata. In Fox, H.M. (Ed.). Biologycal Reviews of the Cambridge Philosophical Soc. 16: 106-133.

Robinson, E.H., LaBomascus, D., Brown, P.B. and Linton, T.L. 1987. Dietary calcium and phosphorus requirements of Oreochromis aureus reared in calcium-free water. Aquaculture 64: 267-276

Robinson, E.H., Rawles, S.D., Yette, H.E., and (ireene, L.W. 1984. An estimate of the dietary calcium requirement of fingerling Tilapia aurea reared in calcium-free water. Aquaculture 41: 389-393.

Robinson, E.H., Rawles, S.D., Brown, P.B., Yette, H.E., and Greene, L.W. 1986. Dietary calcium require. ment of channel catfish Ictalurus punctatus, reared in calcium-free water. Aquaculture 53: 263-270.

Sandifer, P.A. and Smith, T.I.J. 1985. Freshwater prawns. In: Huner, J.V. and Brown, E.E. (Eds.). Crustacean and Mollusk Aquaculture in the United States. AVI Publ. Co. Inc. Connecticut. p. 63-125.

Steel, R.G.D. and Torrie, J.H. 1980. Principles and Procedures of Statistics. Mc(iraw-Hill Book Co.

Sukadi, M.F. 1989. Responses of the Freshwater Prawn, Macrobrachium Rosenbergii to Different Levels of Water Hardness and Dietary Calcium. Ph.D. Dissertation. Auburn Univ. Auburn AL. 75 pp.

Sukadi, M.F. 1995. The influence of water hardness on giant freshwater prawn (Macrobrachium rosenbergii de Man) spawning and egg production. Indonesian Fish. Res. J. I(1): 11-22.

Sze, C.P. 1973. The biochemical composition of juvenile of Macrobrachium rosenbergii. Malaysian Agric. J. 49(8).

Tave D. and Tave, K.B. 1984. A technique to construct hapas from fiberglass window screen using heat sealer. Prog. Fish Cult. 46: 145-146.

Vasquez C.O.E. 1984. Microscopical and Ultrastructural Observations of Hepatopancreas (Midgut (Gland) on Macrobrachium rosenbergii Rafinesque in Different Water Hardness Levels. M. $\mathrm{S}$. Thesis. Auburn Univ. Auburn AL. 